\title{
MATERIAEY
}

Stawomir Jędraszak

DOI: $10.14746 /$ BHW.2015.33.7

Instytut Archeologii i Etnologii,

Zaktad Archeologii Śródziemnomorskiej

Uniwersytet Gdański

\section{Edukacyjna funkcja koroplastycznych przedstawień terakotowych z Egiptu okresu grecko-rzymskiego, na podstawie wybranych grup zabytków}

\begin{abstract}
The Educational Function of Terracotta Representations from Egypt in the Graeco-Roman Period

The subject of this paper aims to investigate problems associated with selected examples of terracotta drawn from the wide iconographic range of figurines produced in Egypt during the Graeco-Roman period. It attempts to find an answer to the question of whether, in the case of the categories of figurines and terracotta plaques, there are any associations or correlations with upbringing and education.

The author maintains that the terracotta figurines, which are the subject of this paper, could include, among many others, examples evoking patterns of appropriate behaviour. Some figurines also played a significant part in the history of Graeco-Roman Egypt, forming an important source for the promotion of a range of information with a socio-political content.
\end{abstract}

Keywords: hellenistic and roman Egypt, terracotta, education

Sztuka i rzemiosło koroplastów stanowią przedmiot licznych opracowań oraz studiów analizujących zabytki terakotowe zarówno w kontekście ich diachronicznego ikonograficznego rozwoju, technologicznych zmian, czy stylistycznych przeobrażeń w obrębie wybranych tematów, jak i zabytków identyfikowanych z konkretną pracownią-warsztatem. Funkcje rzeczonych artefaktów, głównie tych pochodzących z okresu grecko-rzymskiego Egiptu, wielokrotnie zostały już analizowane, zwłaszcza w aspekcie religijnego znaczenia poszczególnych form ikonograficznych. Zabytki, o których mowa, studiowano również w kontekście określenia ich funkcji, identyfikując je słusznie z religią ${ }^{1}$. Ich m.in.

${ }^{1}$ F. Dunand, Religion populaire en Egypte romaine: Les terres cuites isiaques du Musée du Caire (Études preěliminaires aux religions orientales dans l'empire romain 76), Leiden 1979; F. Dunand, Religion Populaire 
statuaryczne formy, umożliwiają także studiowanie szeregu kwestii identyfikowanych z kulturą świata starożytnego, czy ówcześnie panującą estetyką, modą, nawiązującą też do znaczących wydarzeń i przemian o naturze i charakterze politycznym.

Zabytkom terakotowym, omawianym w artykule, należy również przypisać funkcje edukacyjne, widoczne w przekazywaniu odpowiednio formułowanych plastycznie obrazów - tematów, stanowiących istotne dla ówczesnego społeczeństwa wartości, w tym mające walor wychowawczy, i promujące odpowiednie społeczne postawy.

Zabytki identyfikowane ze sztuką koroplastów często odnajdywano podczas badań archeologicznych zarówno w kontekście szerszej przestrzeni sakralnej, gdzie stanowiły wówczas wota dla świątyń, czy sanktuariów ${ }^{2}$, jak i w zespołach grobowych. Tak jak odnotowano to m.in. w przypadku kunsztownie wykonanych i wykończonych zabytków zaliczanych do grupy tzw. Tanagryjek ${ }^{3}$. Statuaryczne figurki terakotowe występowały również w przestrzeni prywatnego domostwa, funkcjonując wtedy jako obiekt indywidualnego czy też rodzinnego kultu ${ }^{4}$, stanowiąc tanią alternatywę wystroju wnętrza, bowiem w twórczości koroplastycznej odwoływano się też do dzieł rzeźbiarskich, w tym i do rzeźby pełnej tak okresu klasycznego, jak i hellenistycznego. Uogólniając, należy stwierdzić, iż walory estetyczne, związane z modelowaniem, czy też plastycznym opracowaniem formuły poszczególnych przedstawień statuarycznych, widoczne są stosunkowo wyraźnie już na przykładach statuetek pochodzących z II w. przed Chr.

et iconographie en Égypte hellénistique et romaine, w: Visible Religion, Annual for Religious Iconography, Popular Religion, Vol. III, red. H.G. Kippenberg i in, Leiden 1984, s. 18-42; S. Jędraszek, Religijne znaczenie sztuki koroplastów na przykładzie zabytków pochodzących z Egiptu okresu grecko-rzymskiego, „Przegląd Religioznawczy" 3 (248), 2013, s. 3-21.

${ }^{2} \mathrm{Z}$ obszarów Śródziemnomorza znane są liczne depozyty figurek terakotowych. Jeden z takich zbiorów odkryty został w kolonii greckiej w Italii, w Lokrach, w źródle przy sanktuarium nimf. Zlokalizowano tam kilkaset terakotowych statuetek, stanowiących laki (Korai), które składane były przez dziewczęta jako ofiary dla nimf, za.: A. Wypustek, Życie rodzinne starożytnych greków, Wrocław 2007, s. 61-61.

${ }^{3}$ Nazwa wywodzi się od miasta Tanagra, położonego w Beocji, gdzie na początku 1870 r. odnaleziono wiele figurek terakotowych, ukazujących kobiety przedstawione w różnych pozach. Styl ten zawiera także i inne kategorie grup ikonograficznych, tj. dzieci, chłopców i młodzieńców, oraz figurki ukazujące Erosów, aktorów, i inne tematy. Na temat tego stylu, jego proweniencji, technologii oraz datowania, zob.: L. Burn, R. Higgins, Catalogue of Greek terracottas in the British Museum. Vol. III, London 2001; G. Kleiner, Tanagrafiguren. Untersuchungen zur hellenistischen Kunst und Geschichte, Berlin 1942; D. Burr Thompson, The Origin of Tanagras, AJA 70, 1, 1966, s. 51-63. Terakoty tego stylu są jedną z najbardziej rozpowszechnionych i charakterystycznych grup, występujących w basenie Morza Śródziemnego, (M.L. Bernhard, Historia starożytnej sztuki greckiej, t. IV, Sztuka hellenistyczna, Warszawa 1993, s. 496-501). Wiele katalogów prezentujących kolekcje koroplastycznych wyobrażeń, m.in. z Egiptu hellenistycznego czy rzymskiego, zawiera zabytki zaliczane właśnie do tej kategorii: D.M. Bailey, Catalogue of the Terracottas in the British Museum, Vol. VI, Ptolemaic and Roman Terracottas from Egypt, London 2008, s. 1, 3, 5, 67, 70, 133-134, 135 nn.); F. Dunand, Catalogue des terres cuites grèco-romaines d'Egypte, Paris 1990, s. 13-15. Zob. również: A. Świderkówna, Hellenika, Wizerunek Epoki od Aleksandra do August, Warszawa 1995, s. 289.

4 S. Jędraszek, Kult domowy na przykładzie wybranych zabytków kaplic terakotowych pochodzacych z Egiptu okresu grecko-rzymskiego, „Przegląd Religioznawczy” 4, 254, 2014, s. 51-61; S. Jędraszek, Religijne znaczenie..., s. 3-23; Szeroko na temat religijnego znaczenia sztuki koroplastów zob.: F. Dunand, Religion populaire ....; C. Boutantin, Terres cuites et culte domestique: bestiaire de l'Égypte gréco-romaine, (Religions in the Graeco-Roman world 179), Leiden, Boston 2014. 
Przedmiotem niniejszego artykułu jest próba skorelowania wybranych przedstawień figuralnych, które - jak należy sądzić - spełniać mogły funkcje edukacyjne, przekazując istotne dla ówczesnego społeczeństwa wartości związane z religią, mitami (zarówno o greckiej, jak i miejscowej egipskiej proweniencji), oraz treściami identyfikowanymi z ówcześnie panującymi modelami wychowania, jak m.in. wychowaniem efebów. W miejscu tym należy jednak zauważyć, że wartości symboliczne interesujących nas tutaj statuetek (czy też innych sformułowań terakotowych), a interpretowanych jedynie na płaszczyźnie ikonograficznej, nastręczają wiele problemów badawczych. Statuetki mogły bowiem posiadać szeroką wartość znaczeniową wynikającą tak z pierwotnego miejsca ich zdeponowania ${ }^{5}$, jak i zilustrowanego tematu, niekiedy o złożonej narracji, odwołującej się nie tylko do świata greckiej kultury, religii i mitologii, lecz także przywołujących tradycje, głównie religijne identyfikowane z egipską cywilizacją ${ }^{6}$. Dlatego też edukacyjne funkcje terakotowych wyobrażeń statuarycznych, plakiet, nieograniczające się tylko i wyłącznie do objaśniania głównych mitów, jak m.in. mitu o Izydzie czy Ozyrysie, także odgrywają rolę umożliwiającą rozpoznanie oraz identyfikację i interpretację istotnych treści odnoszących się do społecznych aspektów, w tym wydarzeń politycznych, zyskując często narrację ideologiczną, czy też właśnie społeczną.

Należy również zauważyć, że część, być może nawet większa niż niekiedy jesteśmy w stanie przypuszczać, terakotowych statuetek szczególnie z ruchomymi elementami mogła zostać wykorzystana jako zabawki ${ }^{7}$, mając przy tym, co należy podkreślić, walory edukacyjne, mogła spełniać także określoną rolę w paideia.

Za klasyczny przykład sztuki koroplastów, jednoznacznie odwołujący się do nauki, czy też szerzej - edukacji, może posłużyć figuralne przedstawienie pedagoga ukazanego wraz z uczniem. Terakotowa statuetka z IV-III w. przed Chr., obecnie znajdująca się

\footnotetext{
${ }_{5}$ Niestety tak istotne informacje, jak kontekst archeologiczny, w przypadku licznych kolekcji zabytków terakotowych są współcześnie nieznane i niedostępne, co wpływa m.in. na szeroki zakres ich chronologicznej identyfikacji opartej często na wątkach ikonograficznych.

${ }^{6}$ Jeden z takich przykładów stanowić może ikonograficzny obraz Harpokratesa. Bóstwa, które m.in. w sztuce koroplastów wyobrażane było w konwencji dziecka, z palcem dotykającym ust. Gest ten w myśl przekazu Plutarcha, zawartego w traktacie teologicznym, O Izydzie i Ozyrysie, ilustrującym religijne tradycje starożytnego Egiptu, należy w kontekście Harpokratesa uważać ...za przewodnika i nauczyciela rozumnego mniemania o bogach, które jest u ludzi zawsze niepetne, niedojrzałe i jakby dziecinne. Bóg ten trzyma więc palec na ustach - symbol ciszy i milczenia, (Plut., De Is. Et Os., 378 c), wg przekładu A. Pawlaczyk. Zob. A. Pawlaczyk, De Iside et Osiride = O Izydzie i Ozyrysie, Fontes Historiae Antiquae (1998) 4, Poznań 2003. Tak jak słusznie zauważył A. Niwiński, charakterystyczny w ikonografii gest Harpokratesa, który wkłada palec do ust, Plutarch interpretował jako gest nawoływania do milczenia, który zawiera w sobie typowo grecką myśl, A. Niwiński, Bóstwa, kulty i rytuały starożytnego Egiptu, Warszawa 2004, s. 53.

7 Wykopaliska archeologiczne na obszarze całego Śródziemnomorza dostarczają licznych przykładów lalek, formowanych z różnych materiałów, jak drewna, kości, kości słoniowej, i z terakoty. I tak dla przykładu z Koryntu pochodzi interesująca terakotowa figurka lalki datowana na pocz. V w. przed Chr., zob.: M.L. Bernhard, Historia starożytnej sztuki greckiej, t. III, Sztuka hellenistyczna, IV w. p.n.e., Warszawa 1992, s. 578-580, il. 428; Jak słusznie wskazywała H. Szymańska, część figurek terakotowych wyobrażająca rozmaite zwierzęta mogło zostać wykorzystywana jako zabawki dziecięce, zob. H. Szymańska, Egipskie figurki terakotowe z okresu ptolemejskiego i cesarstwa rzymskiego w zbiorach Muzeum w Krakowie, „Materiały Archeologiczne” 21, 1981, s. 166, nr 65,66. tabl. VII, 4, VII,7. Zob. również: J. Chesterman, Collecting Classical Terracotta Figures, „Minerva” 1 (9), 1990, s. 35; M.M. Launey, Recherches sur les armées hellénistiques, I-II, Paris 1949-1950, s. 810.
} 


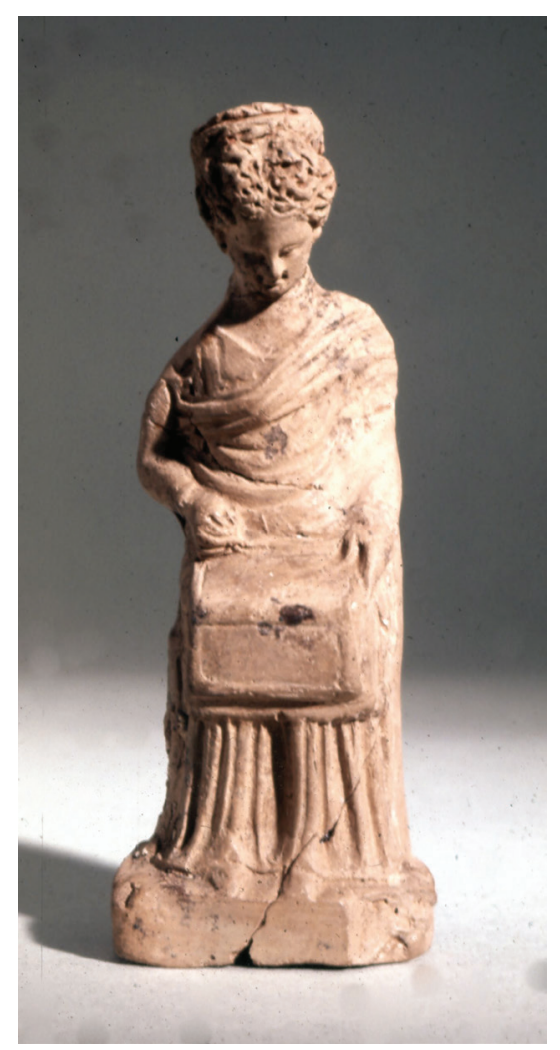

Ryc. 1. Terakotowa statuetka wyobrażająca siedzącą dziewczynę z tablicą, koniec IV, pocz. III w. przed Chr., Cypr, (CThe Trustees of the British Museum

w zbiorach Metropolitan Museum of $\mathrm{Art}^{8}$, to wyjątkowo interesujący przykład rzemiosła terakotowego. Zabytek, choć niepochodzący z Egiptu, odnaleziony został bowiem w Azji Mniejszej, w sposób jednoznaczny w swojej treści ikonograficznej odwołuje się do takich wartości, jak doświadczenie, mądrość czy wiedza. Przymioty te ma symbolizować postać pedagoga, i podkreślać jego podeszły wiek. Pedagog - co może stanowić kolejną interesującą cechę omawianej statuetki - swoją przedstawieniową konwencją przywołuje także niektóre obrazy łączone ikonograficznie z Dionizosem czy Sylenem9 . Bóstw, które w sztuce koroplastów zarówno Grecji, jak i hellenistycznego czy rzymskiego Egiptu występowały nader często ${ }^{10}$. Ów starzec, wyobrażony w pozycji siedzącej, z tablicą na kolanach przedstawiony został w sposób niezwykle realistyczny. Postać nauczyciela spogląda w stronę swojego ucznia, który zdaje się patrzeć na tablicę. Opisywana grupa, podobnie jak zbliżony ikonograficznie zabytek z British Museum ${ }^{11}$, wymownie świadczą

${ }^{8}$ H. A. Thompson, D.B. Thompson, S. I. Rotroff, Hellenistic pottery and terracottas, Princeton 1987, s. $195-196$.

9 Zob. m.in. V. Dasen, Dwarfs in Ancient Egypt and Greece, Oxford 1993, s. 204; H. A. Thompson, D.B. Thompson, S. I. Rotroff, Hellenistic pottery..., s. 116, 389.

${ }^{10}$ D.M. Bailey, Catalogue of the Terracottas...s. 94; F. Dunand, Catalogue des terres cuites..., s. 54-56.

${ }^{11}$ L. Burn, R. Higgins, Catalogue of Greek terracottas..., s. 69-70, nr 2142, tabl. 27. 
o zainteresowaniach koroplastów tematem identyfikowanym z edukacją i wiedzą. Przykład ten stanowi także jaskrawy dowód przemawiający za tym, że rzemiosło koroplastyczne czerpało inspiracje z codziennych, niekiedy nawet prozaicznych czynności ${ }^{12}$.

Znamienną cechą rzemiosła koroplastycznego w Egipcie, tak jak i innych przykładów tego rodzaju źródeł, wywodzących się z różnych części świata starożytnego, jest bogactwo ikonograficzne terakotowych wyobrażeń, które inspirowane było zarówno religią, mitem, jak też rytuałem i kultem. Cechy te, jak należy sądzić, interpretować możemy wielowarstwowo. Tak jak już nadmieniano wcześniej, w terakotowych wyobrażeniach odnajdujemy narrację, stanowiącą echa politycznych wydarzeń czy też militarnych zmagań, ale są też przykłady zawierające częste odniesienia do wspaniałych i imponujących dzieł rzeźbiarskich epoki klasycznej czy hellenistycznej oraz wyobrażenia stanowiące ilustracje sztuk teatralnych czy wyobrażenia postaci identyfikowanych z bohaterami ważnych utworów literackich ${ }^{13}$.

Terakotowe zabytki często prezentowały aktorów dramatycznych czy maski teatral$\mathrm{ne}^{14}$. Zabytki te charakteryzują się ogromnym kunsztem ich wykonania. Cecha ta wydaje się być znacząca, szczególnie jeśli zwrócimy uwagę na wspaniałą polichromię towarzyszącą części statuarycznych przedstawień, co stanowi wymowny dowód odwołujący się do ich artystycznego charakteru.

Już nawet pobieżny ogląd licznych statuetek znajdujących się w kolekcjach muzealnych pozwala wysunąć wniosek, że w niektórych przykładach interesujących nas tutaj zabytków dostrzec możemy często zawiłą i złożoną (czy wręcz wieloznaczną) narrację dowołującą się do wielu elementów identyfikowanych z ówczesną kulturą, w tym religią, estetyką, czy też aspektów wiązanych z szeroko rozumianą obyczajowością. Dlatego też niektóre tematy rodzajowe wyobrażone w koroplastycznym rzemiośle egipskim okresu grecko-rzymskiego identyfikować należy także z wartościami edukacyjnymi, co w sposób oczywisty nie wyklucza przypisywania tej grupie zabytków funkcji i znaczeń religijnych.

Co zrozumiałe, nie sposób w tak krótkim opracowaniu przedstawić całego bogactwa terakotowych formul, jak też odnotować szeregu odrębnych elementów graficznych współtworzących spójny ikonograficznie obraz, a wpływających na symboliczne znaczenia i wartości, które - jak należy sądzić - w starożytności mogły i miały zostać odczytane, i zinterpretowane zarówno przez miejscową, to jest egipską ludność, czy też jej war-

12 Zob. również rzymską statuetkę terakotową wyobrażającą siedzącą dziewczynę z tablicą (L. Burn, R. Higgins, Catalogue of Greek terracottas... s. 235, nr 2749, tabl. 122; J. Fischer, Griechisch - römische Terrakotten aus Ägypten. Die Sammlungen Sieglin und Schreiber Dresden, Leipzig, Stuttgart, Tübingen, Tübinger Studien zur Archäologie und Kunstgeschichte, Bd. 14, Tübingen 1994, s. 130, nr 52, tabl. 8. Zabytek ten (podobnie jak i inne figurki zbliżone ikonograficznie) przemawia, wraz z innymi źródłami historycznymi, o dostępie kobiet do edukacji, R. Cribiore, Gymnastic of the Mind. Greek Education in Hellenistic and Roman Egypt, Princeton 2001, s. 83-84, il. 12; O kobiecej edukacji w okresie grecko-rzymskiego Egiptu i jej charakterze zobacz również, R.S. Bagnall, R. Cribiore, Women's letters from ancient Egypt, 300 BC-AD 800, Ann Arbor 2006, s. 48 i in.

13 Zob. m.in. D.M. Bailey, Catalogue of the Terracottas..., s. 136.

${ }_{14}$ Zob. interesujący zabytek (odnaleziony w Fajum, datowany na III w. przed Chr.) wyobrażający najprawdopodobniej komicznego aktora jako Sokratesa, D.M. Bailey, ibidem, s. 138, $3502_{\text {GR }}$, tabl. 92. 


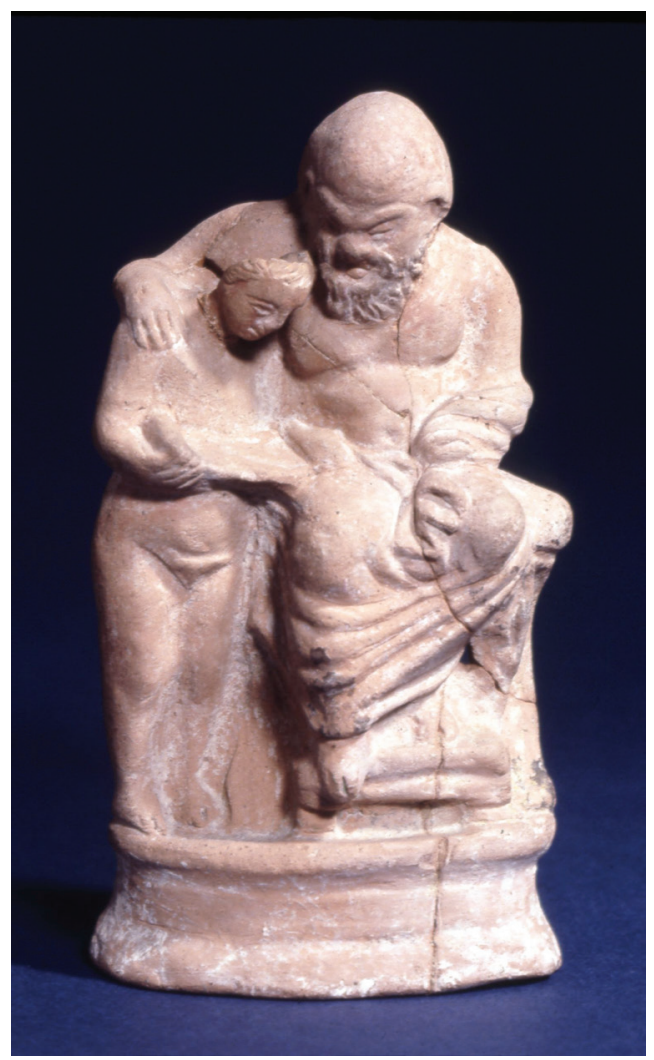

Ryc. 2. Terakotowa grupa ilustrująca lekcję czytania, około I w. przed Chr., Myrina (Azja Mniejsza), (CThe Trustees of the British Museum

stwy zhellenizowane, kształtowane w duchu greckiej kultury, jak i przez ludność kulturowo identyfikującą się z greckim dziedzictwem czy rzymską kulturą, mających także rzymskie obywatelstwo. Dlatego też, w niniejszym artykule przytoczono kilka przykładów zabytków koroplastycznych, których wartości ikonograficzne identyfikować możemy z szeroko rozumianą edukacją, wychowaniem, czy także kształtowaniem i formułowaniem odpowiednich społecznych postaw nie tylko tożsamych z politycznymi wzorcami i uwarunkowaniami, lecz także podyktowanych religijnymi i obyczajowymi zachowaniami i wymogami.

Jedną z takich grup terakotowych może być zespół zabytków wyobrażających wojowników pieszych i konnych ${ }^{15}$. W grupie tej zbiorem zabytków, który dzięki swojej

${ }^{15} \mathrm{Na}$ temat tej grupy zabytków zob. m.in.: S. Jędraszek, Wybrane przykłady terakotowych przedstawień figuralnych o tematyce militarnej: Egipt okresu grecko-rzymskiego, w: Wybrane problemy badawcze historii wojskowej. W pancerzu i mundurze, red. K. Kościelniak, Z. Pilarczyk, Toruń 2014, s. 11-42. Należy również zauważyć, że część statuetek wojowników, głównie o groteskowych czy komicznych elementach składających się na ich formułę ikonograficzną, identyfikowana być może z postaciami nowej komedii, ilustrując utwory Menandra, w których poruszano m.in. tematykę wojenną, jak w utworze pt. Tarcza, ukazującym wojnę z całym jej realizmem; czy też w innej sztuce pt. Obcięty warkocz (Ostrzyżona) analizującej cechy psychologiczne postaci żołnierza, zob. A. Świderkówna, Hellenika ..., s. 41-44. Zob. również m.in.: M. Seif El-Din, M-D. Nenna, La petite plastique en fä̈ence du musée gréco-romain d'Alexandrie, „Bulletin de correspondance hellé- 
ikonografii identyfikowany być może z procesem edukacyjnym, znanym też z licznych innych kategorii źródeł o charakterze i naturze historycznej czy też archeologicznej, są stosunkowo liczne figurki wyobrażające efebów ${ }^{16}$, macedońskich chłopców, ubranych w chiton ${ }^{17}$ oraz chlamidę ${ }^{18}$, buty krepides oraz na głowie filcowy, macedoński beret kausia $^{19}$. Datowanie pierwowzorów tego typu plastycznych form należy wiązać chronologicznie z końcem IV pocz. III w. przed Chr. ${ }^{20}$. Niemniej częste występowanie tego tematu (chlamidophoroi, kausiaphoroi) w koroplastyce przypada na okres II-I w. przed Chr. ${ }^{21}$. Ogromne możliwości interpretacyjne związane $\mathrm{z}$ ikonografią i tematem tak ukształtowanych figurek nie wykluczają wartości edukacyjnych czy wychowawczych,

nique", 118, 1994, s. 331. Koroplastyka egipska okresu hellenistycznego dostarcza licznych przykładów statuetek, które wyobrażają, jak należy przypuszczać najemników służących w armii ptolemejskiej, zob. m.in.: S. Jędraszek, Wybrane aspekty odnoszące się do obecności celtyckich najemników w siłach militarnych Lagidów, w: Celtica. Studia z dziejów Celtów I, red., D. Waszak, Kalisz-Oświęcim 2013, s. 71-92; S. Jędraszek, Wybrane przykłady terakotowych statuetek wyobrażajacych wojowników nubijskich z Egiptu okresu greckorzymskiego. Temat do dyskusji, w: Res Militaris II, red., D. Waszak [praca w druku].

${ }^{16}$ Zob. m.in.: G. Schneider-Herrmann, About The Significance of Alexandrian Terracottas, w: Alessandria e il mondo ellenistico-Romano: studi in onore Achille Adriani, a cura di Nicola Bonacasa e Antonino di Vita. Studi e materiali 5, Roma 1984, s. 304, tabl. LV, 1; L. Török, Hellenistic and Roman Terracottas from Egypt (Bibliotheca Archaeologica 15), Roma 1995, s. 54; P.G. Leyenaar-Plaisier, Les terres cuites grecques et romaines: catalogue de la collection du Musée national des antiquités a Leiden (Collections of the National Museum of Antiquities at Leiden : C.N.M.A.L., v.3), Leiden 1979, s. 528, tabl. 198, nr 1538; J. Fischer, Griechisch - römische Terrakotten aus Ägypten, s. 160, nr 196, tabl. 17; A. Adriani, Annuaire du Musée Gréco-Romain (1935 - 1939), Alexandrie 1940, s. 78-79, tabl. XXXII, 2. Instytucje efebii znane są z ptolemejskiego Egiptu dzięki dokumentom pochodzącym z II i I w. przed Chr. (Ch. Fischer-Bovet, Army and Society in Ptolemaic Egypt Cambridge 2014, s. 284 nn.).

17 W warunkach Egipskich z adaptacją m.in. chitonu mamy do czynienia już w okresie osadnictwa Greków w Egipcie, jeszcze przed podbojem tego kraju przez Aleksandra III Macedońskiego. I tak na jednym z nagrobków z Abusir, datowanym na lata ok. 500 przed Chr., przedstawiającym scenę protesis, wyobrażona została postać w cienkim, najprawdopodobniej lnianym chitonie, sięgającym do łydki, z rękawami prawie do łokci, z krótką chlamidą zarzuconą na ramionach, zob. T.F.R.G. Braun, The Greeks in Egypt, w: $C A H^{2}$ III 3, s. 45-46, il. 3; Chiton bez rękawów należy klasyfikować jako tradycyjny chiton grecki, zob. N.V. Sekunda, A Macedonian Companion in a Pompeian Fresco, „Archeologia” LIV, 2003, s. 32. Chiton oraz himation często występuje na malowanych stelach nagrobnych z nekropolii aleksandryjskich, zob. A. Adriani, Annuaire du Musée..., s. 77-78.

${ }^{18}$ W opinii J. Fischer, strój ten rozpowszechniony został w III w. przed Chr., J. Fischer, A triumphant Macedonian horseman: Evidence of a Ptolemaic Victory Monument, w: Faraoni come dei, Tolemei come Faraoni, Atti del V Congresso Internazionale Italo-Egiziano Torino, Archivio di Stato 8-12 Dicembre 2001, red. red.: N. Bonacasa, A.M. Donadoni, Roveri, S. Aiosa, P. Miná, Torino 2003, s. 377; Zob.: B.M. Kingsley, The cap that survived Alexander, AJA 85 (1) 1981, s. 40; W terakocie przedstawienia chłopców ubranych w chlamidy, krepides i kausia, pojawiają się w ostatniej ćwierci IV w., na obszarach wschodniej części basenu Morza Śródziemnego. Spopularyzowanie tego tematu w sztuce nastąpiło w III w. przed Chr., zob. B.M. Kingsley, The Kausia Diademophoros, AJA 88 (1) 1984, s. 67. Zabytki z Aleksandrii znane są m.in., z nekropoli Szatbi, Hadra, czy Ibrahimeia, zobacz, S. Ashour, An Unpublished Grenite statue of Diskophoros Ephébos in Cair, BIFAO 112, 2012, s. 31.

${ }^{19}$ Chr. Saatsoglou-Paliadeli, Aspects of Ancient Macedonian Costume, JHS 113, 1993, s. 122-147; F. Dunand, Catalogue des terres cuites ..., s. 210, 212-213, nr 571-578 ( E 15000, E 16139, E 16143, AF 8320, AF 8321, AF 8322, AF 8323 E 20900bis); A. Adriani, Annuaire du Musee greco-romain (1940-1950), Alexandrie 1952, s. 14, tabl. VI, 1; zob. również S. Müller, Das hellenistische Königspaar in der medialen Repräsentation: Ptolemaios II. und Arsinoe II. (Beiträge zur Altertumskunde Bd. 263), Berlin, New York 2009, s. 357.

20 Ten typ ikonograficzny był także rozpowszechniony w greckim rzemiośle koroplastycznym, zob. L. Burn, R. Higgins, Catalogue of Greek terracottas ... , s. 64-69, tabl. 21-25.

21 H. Szymańska, Egipskie figurki terakotowe..., s. 164, nr 57, tabl. VI, 6. 
odwołujących się do modelu wojskowego kształtowania chłopca w duchu greckiej kultury i religii. W takim ujęciu figurki przedstawiające chłopców w macedońskich strojach wojskowych ${ }^{22}$, ponadto $\mathrm{w}$ narodowym nakryciu głowy w postaci charakterystycznego beretu funkcjonowałyby jako swoisty model, czy też wzorzec. Niekiedy wykorzystywane być mogły także jako przedmioty służące do zabawy dla dzieci, co w konsekwencji w przyszłości mogło wpłynąć na chęć szkolenia się młodych chłopców w rzemiośle woskowym i ambicję służenia w ówczesnych strukturach militarnych, czy to w formacjach konnych, czy też w formacjach pieszych. A sama chlamida - być może - stanowiła symbol wojskowej edukacji efeba.

Funkcja taka, omawianego zespołu zabytków koroplastycznych, nie wyklucza ich przeznaczenia wotywnego. W tym wypadku omawiane statuetki mogły zostać ofiarowane przez samych efebów zarówno bóstwom o greckim, jak i egipskim rodowodzie ${ }^{23}$. Ponadto należy również nadmienić, że zgodnie z sugestią R.M. Errington ${ }^{24} \mathrm{w}$ Egipcie doby hellenistycznej mamy również do czynienia z prywatną - jak określa to badacz inicjatywą żołnierzy osiedlonych na gospodarstwach w delcie Nilu oraz w Fajum zakładania gimnazjonów ${ }^{25}$. Tak więc należy stwierdzić, że część terakotowych statuetek, szczególnie identyfikowanych lub nawiązujących swoją tematyką do symboli i wartości militarnych, mogła posiadać związek z gimnazjonami, palaistra. Tam rzeczone figurki mogły spełniać rozmaite funkcje, od edukacyjnych czy stanowiących indywidualne pamiątki, aż do ich przeznaczenia jako np. wota, adresowane do konkretnych opiekuńczych bóstw ${ }^{26}$. Stąd też, być może niektóre z przedstawień owych bóstw w koroplastyce egipskiej okresu grecko-rzymskiego przyjęły również militarne cechy ikonograficzne. Fakt taki dostrzegalny jest zarówno w wyobrażeniach terakotowych pewnych bogów i bogin o greckim $^{27}$, jak i o egipskim pochodzeniu.

${ }^{22}$ Chlamida stanowiła ubiór macedońskiego dworu, D.B. Thompson, Troy, The Terracotta Figurines of the Hellenistic Period, (Supplementary Monographs, 3), Princeton 1963, s. 54, nr 144.

${ }^{23}$ Jak podkreśla Ch. Fischer-Bovet, z gimnazjonem związani byli również i Egipscy bogowie, co zdaniem badaczki sugeruje obecność, w samym gimnazjonie oprócz Greków i Macedończyków, także i Egipcjan (Ch. Fischer-Bovet, Army and Society ..., s. 285). Należy zauważyć, że część imion mogła ulec procesowi hellenizacji, co w sposób istotny zakłóca naszą ocenę takiego procesu. Trzeba ponadto zwrócić uwagę, jak zaznacza Jean Bingen, iż podstawowa religia egipska nie miała miejsca w edukacji młodych Greków w gimnazjonie, stąd też obecność egipskich bóstwa może być identyfikowana i wiązana z Egipcjanami, J. Bingen, R.S. Bagnall, Hellenistic Egypt: monarchy, society, economy, culture, (Hellenistic culture and society, 49), Berkeley 2007, s. 249.

${ }^{24}$ R.M. Errington, Historia świata hellenistycznego 323-30 p.n.e., przeł. A. Gąsior-Niemiec, Kraków 2010, s. 177-178; Za szczególnie interesujące uznają badacze gimnazjony istniejące na wsiach. W opinii E. Wipszyckiej, obecność gimnazjonów dowodzi istnienia we wczesnym okresie skupisk ludności greckiej, a także cyt., jej zdecydowaną świadomość ważności zaspakajania potrzeb kulturalnych., cyt., za: E. Wipszycką (E. Wipszycka, O starożytności polemicznie, Warszawa 1994, s. 90).

${ }^{25}$ Gimnasia z Egiptu okresu hellenistycznego potwierdzone z III w. przed Chr., zob. m.in. S. Ashour, An Unpublished Grenite statue..., s. 26.

${ }^{26}$ Znamy szereg dedykacji adresowanych od efebów do opiekuńczych bóstw, takich jak m.in. Hermes, Herakles, Amon. Pan, czy Apollo, zob.: Ch. Fischer-Bovet, Army and Society ..., s. 285; S. Ashour, An Unpublished Grenite statue..., s. 21.

${ }^{27}$ Zob. m.in. figuralne wyobrażenia Erosa z tarczą peltasty (E. Breccia, Municipalité d'Alexandrie. Alexandrea ad Aegyptum; Guide de la ville ancienne et moderne et du Musée gréco-romain, Bergamo 1914, 
Ryc. 3. Terakotowa statuetka wyobrażająca chłopca macedońskiego grającego na lutni, Egipt, około 250 r., przed Chr., (OThe Trustees of the British Museum

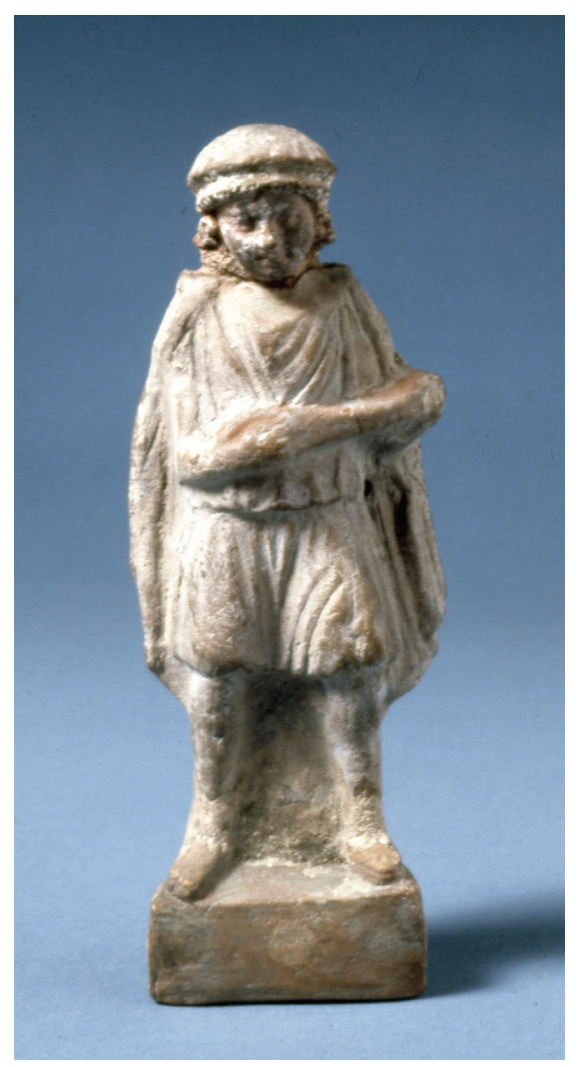

W obrazach i statuarycznych figuracjach bóstw rozpoznać możemy typowe atrybuty o militarnym charakterze lub odwołujące się do walki, jak miecze/noże, czy też tarcze o różnych kształtach, np. tarcze hoplickie, peltastów, czy szczególnie interesujące w przypadku takiego bóstwa, jak apotropaiczny Bes ${ }^{28}$ czy Harpokrates $^{29}$ (grecka forma egipskie-

s. 271-272, fot. 136). Zobacz interesujący zabytek terakotowy wyobrażający Erosa z tarczą typu thureos, znajdujący się w kolekcji Museum für Kunst und Gewerbe, Hamburg; zob. też H.P. Laubscher, Ein ptolemäisches Gallierdenkmal, „Antike Kunst” 30, 2, 1987, 152, fot. 21.7; S. Besques, Catalogue raisonné des figurines et reliefs en terre-cuite grecs, étrusques et romaines: Époques hellénistique et romaine. Cyrénaique, Égypte ptolémaique et romaine, Afrique du Nord et Proche-Orient, Musée du Louvre 1954, Paris 1992, s. 104, fot. 64a; E. Breccia, Municipalité d'Alexandrie ... s. 271-272, fot. 137; L. Török, Hellenistic and Roman Terracottas ... s. 45, nr 36; U. Hausmann, Zur Eroten und-Gallier, Ikonographie in alexandrinischen Kunst, w: Alessandria e il mondo ellenistico - romano, Studi in onore di Achille Adriani 5 (Roma 1992): 284-285; F. Dunand, Catalogue des terres cuites ... s. 61, nr 104 (E 20813) oraz wyobrażenia identyfikowane z Atneą, ibidem, s. 36, nr 19-21, E 20877, E 20894, E 21465.

${ }^{28}$ Szerzej zob. m.in. S. Jędraszek, Wojownicze Bóstwo Bes, „Scripta Biblica Et Orientalia” 4, 2012, s. $145-177$.

29 Na temat Harpokratesa, zob. D. Meeks, Harpokrates, w: Lexikon der Ägyptologie II, Wiesbaden 1977, 1003-1011 (kolumny); H.P. Laubscher, Ein ptolemäisches ... s. 152, 154, tabl. 21,7; P. Perdrizet, Les terres cuites grecques d'Égypte de la collection Fouquet, Nancy-Paris-Strasbourg 1921, s. 115, tabl. XXXII. Zobacz również Harpokratesa, wyobrażonego w konwencji jeźdźca, F. Naerebout, Cuius regio, eius religio? Rulers 
go imienia Heru-pa-khered oznaczająca „Horus dziecko" ${ }^{30}$ ), tarcze celtyckiego typu o owalnym zarysie zwane thureos ${ }^{31}$. Oczywiście, fakt pojawienia się elementów uzbrojenia w ikonografii bóstw wyobrażonych w technice terakoty ma daleko szersze odniesienia, łączone m.in. z samą teologią i przypisywanymi im funkcjami ${ }^{32}$. Dlatego też symboliczna rola takich plastycznych sformułowań o cechach i przeznaczeniu wyraźnie religijnym - identyfikowana z prywatnym kultem czy też indywidualną pobożnością jest jedną z wielu funkcji rzeczonych statuetek. Być może, część z tak uformowanych tematycznie figurek mogła reprezentować związki z osobami szkolącymi się do służby wojskowej, czy też młodymi wojownikami rozpoczynającymi służbę w armii.

Spośród innych przykładów statuetek terakotowych, odwołujących się m.in. do edukacyjnych czy też wychowawczych wartości oraz funkcji, interesującą grupę stanowią wyobrażenia konnych jeźdźców macedońskich w strojach wojskowych. Zabytki, o których mowa, oprócz funkcji identyfikowanych z darami o wotywnym charakterze, mogły - czego nie jesteśmy w stanie współcześnie jednoznacznie wykluczyć - również służyć jako zabawki dla dzieci. Stąd też wyobrażenia militarne jeźdźców w koroplastyce, gdzie podkreślono narodowe cechy, mogły ilustrować postawy czy też stanowić swoisty model wychowawczy, mając przy tym walor edukacyjny.

Podobnie, jak wyżej nadmieniane statuetki wyobrażające efebów, tak również i w przypadku figuralnych przedstawień konnych wojowników w ich ikonografii występuje charakterystyczny macedoński strój wojskowy wraz z kausia, co bez wątpienia łączy ten obraz ideologicznie z macedońskim pochodzeniem królów hellenistycznego Egiptu, to jest Lagidów.

and Religious Changes in Greco-Roman Egypt, w: Power, politics, and the cults of Isis. Proceedings of the Vth International Conference of Isis studies, Boulogne-sur-Mer, October 13-15, 2011, (Religions in the Graeco-Roman world vol. 180, red. L. Bricault, M.J. Versluys, Boston 2014, s. 45; D.M. Bailey, Catalogue of the Terracottas ..., s. 35, $3068_{\mathrm{EA}}$, tabl. 12; F. Dunand, Religion populaire ... s. 239, nr 242, tabl. XCI ; F. Dunand, Catalogue des terres cuites ... s. 84-86, nr 175-179, (AF 1037, AF 7822 B, E 20609 ; E 20610 ; E 20858).

${ }^{30}$ E.S. Meltzer, Horus, w: The Oxford Encyclopedia of Ancient Egypt, Vol. 2, red. D.B. Redford, Oxford 2001, s. 119-122;

${ }^{31} \mathrm{Na}$ temat proweniencji celtyckiej tarczy typu thureos „w kształcie drzwi” [podłużnych drzwi], zob. G.R. Bugh, The Theseia in Late Hellenistic Athens, „Zeitschrift für Papyrologie und Epigraphik” 83, 1990, s. 23, tam przypis nr 16. Zob. także: N.V. Sekunda, The Introduction of Cavalry Thureophoroi Into Greek Warfare, „Fasciculi Archaeologiae Historicae” 19, 2006, s. 9-17, oraz N.V. Sekunda, The Antigonid Army, Gdańsk 2013, s. 44, 101, 115, 119.

${ }^{32}$ Interesjącymi zabytkami pozostają niezykle popularne w okresie grecko-rzymskim wyobrażenia Harpokratesa w konwencji jeźdźca. Bóśtwu temu niekiedy towarzyszy charakterystyczna, prostokątna w kształcie tarcza (F. Dunand, Catalogue des terres cuites..., s. 84-86, nr 175-179, AF 1037, AF 7822B, E 20609, E 20610, E 20858). Należy sądzić, że Harpokratest ukazany w konwencji jeżdźca odwołuje się do treści mitycznej. Plutarch, przekazuje informacje, że Horus do walki z Tyfonem wybrał konia, argumentując Ozyrysowi, iż zwierzę to jest najbardziej skuteczne w walce. Potem Ozyrys powrócit z Hadesu i udat się do Horusa, by ćwiczyć i zaprawiać do walki [...] Zadał mu Ozyrys inne pytanie: jakie zwierzę uważa za najbardziej pożyteczne i mężne w walce. Gdy odrzekł mu Horus: Konia [...] Konia, zdziwit się bóg i zakłopotal, czemu Horus nie wymienit raczej lwa niż konia. Ten jednak wyjaśnil, że lew jest pożyteczny dla tego, kto potrzebuje pomocy, koń natomiast stratowat uciekajacych i zniszczył całkowicie sity wroga [...] przekład Plutarcha wg A. Pawlaczyk, (Plut., De Is. Et Os., 358b-c), A. Pawlaczyk, De Iside et Osiride... 
Ryc. 4. Terakotowa statuetka wyobrażająca jeźdźca macedońskiego w charakterystycznym stroju wojskowym, tratującego wroga, IV-III w. przed Chr., Tell Atrib, Egipt, CThe Trustees of the British Museum

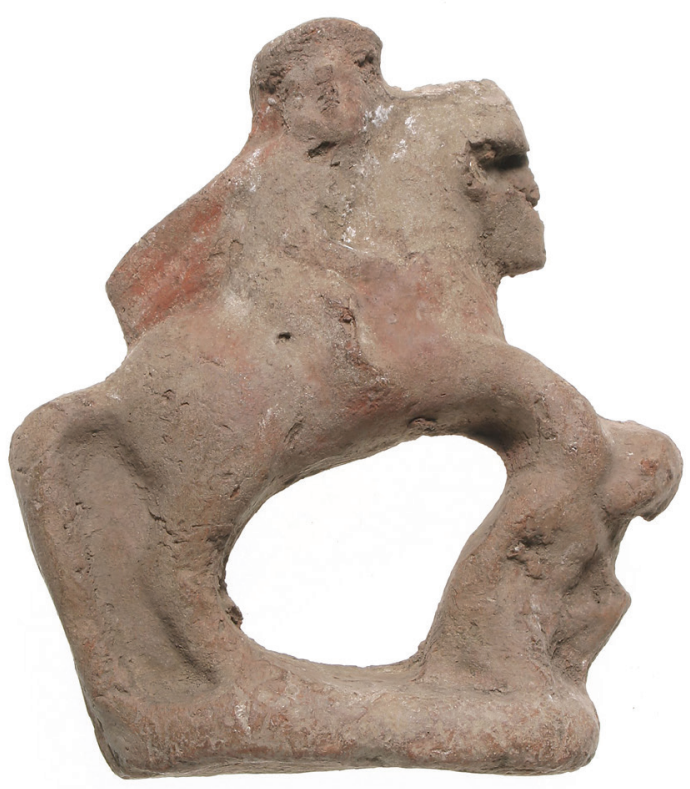

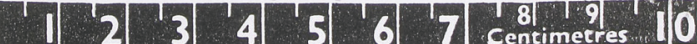

Z polityczną wartością, jak również i ideologiczną przestrzenią, łączyć należy obraz jeźdźców macedońskich tratujących wrogów. W historiografii rozmaicie interpretowano owe zabytki ${ }^{33}$, niemniej zawsze w opinii badaczy obraz ów łączony bywał z treściami o naturze politycznej, identyfikowanymi w okresie hellenistycznym z władzą ptolemejską. W kontekście naszych zainteresowań obraz ten mógł stanowić jaskrawy przekaz odwołujący się przez swoją treść do szerokiego grona użytkowników wytworów terakotowego rzemiosła. W swojej wartości interpretacyjnej symbolizować może władzę królów macedońskich sprawowaną nad Egiptem. Walor edukacyjny, czy też szerzej, treści identyfikowane $\mathrm{z}$ tak uformowanym tematem wydają się być stosunkowo dobrze umoty-

33 Zob.: J. Vogt, Terrakotten (Die griechisch-ägyptische Sammlung Ernst von Sieglin, Bd. 2; Expedition Ernst von Sieglin: Ausgrabungen in Alexandria, Bd. 2; Expedition Ernst Sieglin, Tl. 2.), Leipzig 1924, s. 61, 187; M. Fjeldhagen, Catalogue of Graeco-Roman terracottas from Egypt: Ny Carlsberg Glyptotek, Copenhagen 1995, s. 131; H. Philipp, Terrakotten aus Ägypten im Ägyptischen Museum Berli, (Bilderheft der Staatlichen Museen zu Berlin-Preussischer Kulturbesitz, Heft 18/19), Berlin 1972, nr 43, tabl. 38; A.J. Reinach, Les Galates Dans L'Art Alexandrin, s. 103; F. Dunand, Catalogue des terres cuites..., s. 215; K. Myśliwiec, M.B. Said, Polish - Egyptian Excavations at Tell Atrib in 1994-1995, „Etudes et Travaux” 18, 1999, s. 179121; J. Fischer, Griechisch - römische Terrakotten aus Ägypten, s. 384. J. Fischer, A triumphant Macedonian horseman ... s. 375-380; S. Jędraszek, A Ptolemaic Monument to Victory over the Galatians, w: Gdańskie Studia Archeologiczne 2, red. L. Czerniak, Gdańsk 2012, s. 235-246. 
wowane, zważywszy szczególnie na fakt kreowania imperialistycznej polityki przez pierwszych władców z dynastii ptolemejskiej. Plastyczny wizerunek wojownika o wyraźnie podkreślonych cechach narodowych, to jest macedońskich, wyobrażonego jako jeźdźca tratującego wroga, łączono zapewne z aktualnie dziejącymi się wydarzeniami politycznymi. Sam obraz mógł natomiast symbolizować królewską siłę i władzę. Temat ten, zważywszy na szerokie rozpowszechnienie sztuki koroplastów, mógł zostać rozpropagowany szczególnie wśród niższych warstw ówczesnego społeczeństwa. Stąd też walor edukacyjny związany z obrazem władzy macedońskiej wydaje się być czytelnym przekazem w opisywanym wyżej przykładzie.

Przytoczone dotychczas, w niniejszym tekście, grupy terakotowych form statuarycznych nie dają oczywiście wyobrażenia całości sztuki koroplastów rozwijającej się wyjątkowo intensywnie w Egipcie doby Lagidów, czy też w czasach rzymskiego panowania ${ }^{34}$. Niemniej należy zwrócić uwagę, że motywy graficzne zawarte w terakotowych statuetkach, glinianych plakietach uwarunkowane zostały szeregiem różnorodnych czynników, mając przy tym liczne odwołania do niejednorodnego etnicznie społeczeństwa czasów grecko-rzymskiego Egiptu, jak też uwarunkowane zostały indywidualnymi preferencjami religijnymi ówczesnych odbiorców. Płaszczyzna ikonograficzna owych przedstawień, podobnie jak obecnie otaczające nas rozmaite obrazy o różnorodnej treści, spełniają funkcję w ogromnej mierze informacyjną, wpływając często na kształtowanie odpowiednich postaw czy zachowań. Od zawsze to właśnie często obraz determinował liczne nasze postępowania i reakcje. Nie inaczej obraz - przedstawienie np. figuralne i zawarty w nim przekaz - oddziaływał na swojego odbiorcę w Egipcie okresu grecko-rzymskiego. Ówcześni rzemieślnicy kreujący odpowiednie formuły graficzne, stosując taki a nie inny obraz (taką a nie inną formę), wpływali być może, nawet niekiedy pośrednio, na utrwalenie tożsamości kulturowej. Niektóre z treści ikonograficznych wynikające czy to z politycznych uwarunkowań, czy też mające szersze związki z religią czy kulturą należy z pewnością wiązać z edukacją, a tu szczególnie z profilowaniem i kształtowaniem pewnych oczekiwanych postaw, głównie u młodzieży i dzieci. Jeśli zgodzimy się z taką interpretacją niektórych statuarycznych przedstawień, to tak ukształtowany kierunek w rzemiośle koroplastycznym został kontynuowany w rzymskich wyrobach terakotowych.

Po aneksji Egiptu przez Rzymian, co nastąpiło w konsekwencji przegranej bitwy u przylądka Akcjum, która odbyła się 2 września 31 r. przed Chr., stanowiąc decydujące starcie w trwającej w Imperium Rzymskim, wojnie domowej pomiędzy Oktawianem Augustem a Markiem Antoniuszem i wspierającej go Kleopatrą VII ${ }^{35}$, koroplastyka tego kraju rozwijała się nadal, czerpiąc obficie z tradycji wypracowanych wcześniej, to jest w okresie hellenistycznym.

${ }^{34}$ L. Török, generalnie słusznie zauważył, że najbardziej kreatywnym artystycznie okresem w rozwoju rzemiosła koroplastycznego w Egipcie był przedział chronologiczny od II w. przed Chr. do II w. po Chr., zob.: L. Török, Hellenistic and Roman Terracottas..., s. 25.

${ }^{35}$ Nie sposób w miejscu tym przedstawić szeregu prac odwołujących się do biografii królowej. Zob. m.in.: A. Łukaszewicz, Kleopatra. Ostatnia królowa starożytnego Egiptu, Warszawa 2005; M. Chauveau, Egypt in the Age of Cleopatra. History and Society under the Ptolemies, London 2000; S.M. Burstein, Kleopatra i jej rządy, przeł. B. Godzińska, Warszawa 2008; M. Grant, Cleopatra, London 1974. 
Ryc. 5. Terakotowa grupa przedstawiająca cesarza Hadriana w stroju wojskowym, zabijającego wroga, tutaj zilustrowanego pod postacią Nubijczyka, Egipt, około 118-135 r., po Chr., CThe Trustees of the British Museum

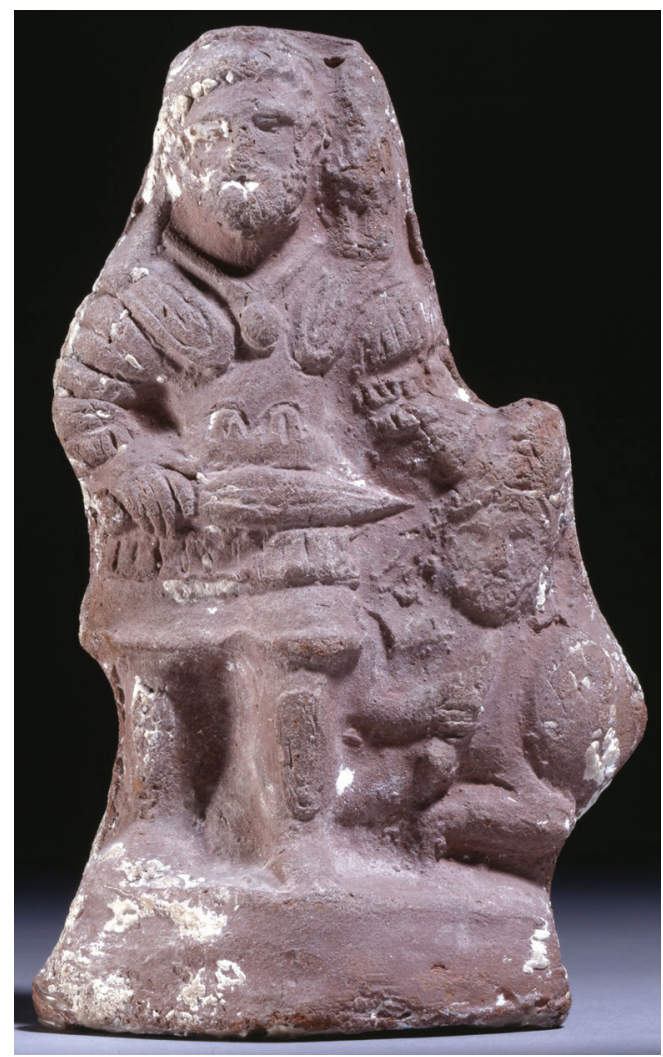

Jednym z klasycznych przykładów późnego terakotowego rzemiosła stanowić może zabytek stanowiący terakotową grupę, a odwołujący się w swojej ikonografii zarówno do egipskiego dziedzictwa, jak i sztuki przedstawieniowej, wykazując także cechy łączące ów obraz z rzymską tradycją ikonograficzną. Mowa jest tutaj o grupie, identyfikowanej

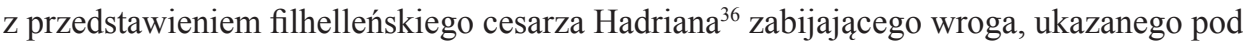
postacią Nubijczyka, z charakterystyczną dla tych wojowników z północy bronią w postaci topora o podwójnym ostrzu ${ }^{37}$. Zabytek znajdujący w kolekcji British Museum, a który odnaleziony został w Tebach, jest wyjątkowo interesujący, zwłaszcza w aspekcie ikonograficznym, przedstawia bowiem rzymskiego wojownika.

Rzeczona grupa identyfikowana przez D.M. Beileya z konkretnymi postaciami cesarzy (w tym również, jak wspominano z cesarzem Hadrianem, 117-138 po Chr.), datowa-

${ }^{36}$ Znane są także inne terakotowe portrety, jak m.in. Marka Aureliusza w greckim ubiorze (D.M. Bailey, Catalogue of the Terracottas..., s. 139; nr 3511 $1_{\mathrm{EA}}$, tab. 93), czy też reliefowe wyobrażenie ptolemejskiego księcia (D.M. Bailey, Catalogue of the Terracottas ..., s. 138; nr 3503 ${ }_{\mathrm{EA}}$, tab. 92.

37 D.M. Bailey, Little emperors, w: Archaeological Research in Roman Egypt, The Proceedings of The Seventeenth Classical Colloquium of The Department of Greek and Roman Antiquities, British Museum, held on 1-4 December, 1993, JRA Suppl. 19, red., D. M. Bailey, Ann Arbor 1996, fig. 3; Strabo, 17.1. 53-54; Zob. m.in.: L. Török, Hellenistic and Roman Terracottas ... s. 156-157, pl. CXXVII, nr 239. 
na została na lata $118-135^{38}$ po Chr. Terakoty te (zbliżona grupa znajduje się w Muzeum w Berlinie, czy też zabytek znajdujący się w kolekcji University of Southern California $^{39}$ ), zgodnie z sugestią brytyjskiego badacza, mają szereg różnorodnych znaczeń, odwołujących się do wydarzeń politycznych związanych tak z Egiptem, jak też i innymi obszarami Wschodu Starożytnego. Pomijając tutaj szeroką dyskusję odnoszącą się do symbolicznych funkcji i przypisywanych temu przedstawieniu treści propagandowych ${ }^{40}$, należy stwierdzić, że omawiane przedstawienia bezsprzecznie łączone być mogą z wartościami ideologicznymi, politycznymi, pełniąc także funkcję informacyjną. Obraz tryumfującego rzymskiego cesarza nad wrogiem odnosić może się do rozpropagowania wiedzy odnośnie do rzymskiego sposobu sprawowania polityki w prowincjach. Walor informacyjny, a tym samym płaszczyzna edukacyjna, w kontekście tego terakotowego zabytku wydają się być jasno i precyzyjnie sformułowane. Co równie interesujące, sam temat wykazuje jeszcze silne związki z ideologią władzy, wypracowaną i podejmowaną w licznych obrazach chronologicznie identyfikowanych z Egiptem okresu dynastyczne$\mathrm{go}^{41}$.

Religijna płaszczyzna sztuki koroplastów, szczególnie widoczna w warstwie ikonograficznej, jest jedną z bardziej dominujących w terakotowych zabytkach zarówno przyjmujących statuaryczną formę, jak i tych ukształtowanych jako plakiety. Powiązanie tej grupy statuarycznych przedstawień z religijną funkcją wynika m.in. z analizy samej ikonografii, przemawiając często za kultową ich funkcją. Należy przy tym zaznaczyć, że często same treści ikonograficzne identyfikować należy z obrazowaniem złożonego i różnorodnego systemu religijnego, odwołując się także do bogactwa rytuału, mitu, często je ilustrując. Stąd też sztuka koroplastów interesującego nas przedziału chronologicznego prezentuje szereg ilustracji bóstw identyfikowanych z greckim systemem wierzeniowym czy mitem (m.in. statuetki wyobrażające Afrodytę, Artemidę, Demeter czy Atenę, Erosa,

38 D.M. Bailey, Catalogue of the Terracottas..., s. 139, nr $3509_{\mathrm{GR}}$ tabl. 93; zob. również D.M. Bailey, Antaios, an Egyptian God in Roman Egypt: extracting an iconography, w, The Proceedings of the 8th International Colloquium on Problems of Roman Provincial Art, red. M. Sanader, A. Rendić-Miočević, Zagreb 2005, s. 389-398.

39 D.M. Bailey, Catalogue of the Terracottas..., s. 139; D.M. Bailey, Little emperors..., s. 207-213; Z. Kiss, Représentations des barbares dans l'iconographie romaine impériale en Égypte, Klio 71, 1989, s. 127-137; Z. Kiss, Un Pharaon Romain, w: Warsaw Egyptological Studies 1, Essays in honour of Prof. Dr. Jadwiga Lipińska, red. J. Aksamit, J. Lipińska, Warsaw 1997, s. 291-296; What Is A King To Do, An Investigation of Images of Kingship, http://www-scf.usc.edu/ grantdix/WhatIsAKingToDo/TheSmitingImage.html (3.11.2014).

${ }^{40}$ D.M. Bailey, Catalogue of the Terracottas..., s. 139.

${ }^{41}$ Jak powszechnie wiadomo, ideologia królewska starożytnego Egiptu przypisuje królowi bardzo istotne atrybuty religijne, ale przedstawia go również jako zwycięskiego wodza. Na wielu zabytkach król ukazany został w klasycznej pozie tryumfu, z wzniesioną do ciosu maczugą - jak na palecie Naremara, drugą ręką trzymając jeńca za włosy. Sceny te na stałe weszły do repertuaru sztuki oficjalnej, stanowiąc istotny element kompozycji reliefowych, będąc wyrazem jednego z wielu aspektów ideologii królewskiej. Zob. m.in. E. Lipiński, Studia z dziejów i kultury starożytnego Bliskiego Wschodu, Kraków 2013, s. 228. 
Apollona, Zeusa, jak też i wyobrażenia identyfikowane z Amazonkami ${ }^{42}$ ), jak również i statuaryczne sformułowania odwołujące się do bogatej miejscowej tradycji i dziedzictwa, o czym dobitnie świadczą nie tylko rozmaite figuracje bogini Izydy ${ }^{43}$, czy apotropaicznego Besa, lecz także statuetki ukazujące boginię Hathor ${ }^{44}$, boga Ozyrysa ${ }^{45}$, czy prastarego Horusa ${ }^{46}$.

Fakty takie umożliwiają podjęcie szerokiej dyskusji, odwołującej się również i do panującej ówcześnie specyfiki kulturowej, czy wątków identyfikowanych z heterogenicznym etnicznie społeczeństwem Egiptu okresu grecko-rzymskiego i jego wewnętrznym, strukturalnym szerokim rozwarstwieniem.

W aspekcie interesującej nas problematyki wizualizacje, czy figuracje bóstw objaśniały często zawiłe i niejednoznaczne w swoich sformułowaniach znaczenia mitologiczne i treści teologiczne oraz naturę poszczególnych bóstw. Omawiane zabytki w sposób niezwykle precyzyjny, dzięki opracowaniu plastycznemu elementów składających się na ich treści, zaznajamiały społeczeństwo z różnorodną tradycją religijną, odwołując się przy tym do szeregu nurtów religijnych. Ponadto, dzięki występowaniu w sztuce kroplastów łączonych formuł, zabytki te mogły integrować ludność wokół kultu czy to synkretycznego boga Serpaisa ${ }^{47}$, czy też bóstw o dawnym egipskim rodowodzie, którym często nadawano nową plastyczną formułę, tak by ich obraz pozostawał w zgodzie $\mathrm{z}$ hellenistyczną tradycją.

Za interesujący przykład posłużyć może ciekawa grupa wyobrażająca najprawdopodobniej kapłana ${ }^{48}$, na którego lewym ramieniu przedstawiono kultowy obraz siedzącego Amona-Mina, gdzie egipski bóg Min ${ }^{49}$ zespolony został z Amonem. Zabytek znajdujący się w kolekcji British Museum, datowany III-II w. przed $\mathrm{Chr}^{50}$, jest wyjątkowo interesujący, tak z punktu widzenia samej ikonografii kapłana (postać ta cechuje się wyraźnie groteskowym wyglądem), jak też i z faktu, iż obraz bóstwa nie jest typowym jego ujęciem w kategoriach graficznych charakterystycznych dla okresu dynastycznego Egiptu.

${ }^{42}$ D.M. Bailey, Catalogue of the Terracottas..., s. 93-106.

${ }^{43}$ Ibidem, s. 9-11, 24-28; F. Dunand, Catalogue des terres cuites..., s. 125-157.

44 D.M. Bailey, Catalogue of the Terracottas..., s. 7-9, 22-24.

${ }^{45}$ F. Dunand, Catalogue des terres cuites..., s. 158-161; D.M. Bailey, Catalogue of the Terracottas..., s. $11-12,28$.

${ }^{46}$ F. Dunand, Catalogue des terres cuites..., s. 125, nr 326, AF 1045.

47 Szerzej zob.: L. Vidman, Isis und Serapis bei den Griechen und Roemern, Berlin 1970; D.M. Bailey, Catalogue of the Terracottas..., s. 12-13.

${ }^{48}$ Postać ta również ma interesujące nakrycie głowy o wyraźnie stożkowej formie. W opinii D.M. Bailey’a nakrycie głowy w postacie rustykalnego stożkowatego kapelusza, często identyfikowane być może z osobami uczestniczącymi w procesjach, D.M. Bailey, Catalogue of the Terracottas..., s. 56.

${ }^{49} \mathrm{~W}$ oficjalnej religii faraońskiej Min zajmował szczególne miejsce, jak bóstwo łączone z prokreacją. W klasycznej ikonografii, Mina wyobrażano jako stojącego mężczyznę owiniętego płótnem. Bóstwo to w jednej ręce trzymało wzniesiony ku górze bicz, drugą obejmował swój penis, w stanie erekcji. Jako nakrycie głowy Min nosił dwa wysokie pióra. Podstawowa forma ikonograficzna Mina pojawiła się już w okresie II dynastii, W.M. Flinders Petrie, Abydos I, London 1902, tabl. III, nr 48; E. Romanosky, Min, w: The Oxford Encyclopedia of Ancient Egypt, vol. 1, red. D.B. Redford, Oxford 2001, s. 413-415.

${ }^{50}$ D.M. Bailey, Catalogue of the Terracottas..., s. 60, $3153_{\text {EA }}$, tabl. 27. 
Nagie bóstwo, z koroną boga Amona uformowaną z piór, dodatkowo na szyi posiada wieniec. Bóg swoją prawą rękę wznosi ku górze, natomiast lewa znajduje się w pobliżu, wyraźnie wymodelowanego fallusa, nie dotykając go jednak. Opisywana tutaj grupa theophoroi $^{51}$, bez wątpienia ilustruje czynność rytualną identyfikowaną z Amonem-Minem, na co wskazuje dodatkowo trzymany przez kapłana przedmiot - być może kadzidło lub muzyczny instrument bullroarer ${ }^{52}$. W kontekście interesującej nas problematyki edukacyjna funkcja m.in. tej statuetki identyfikowana być może z zaprezentowaniem głównych cech odwołujących się do funkcji prastarego bóstwa egipskiego, łączonego z symboliką płodności i wegetacji. Ponadto obraz ów ilustruje również czynności wiązane z kultem tego boga. Podobne spostrzeżenia poczynić możemy w stosunku do statuetki wyobrażającej kapłana noszącego maskę boga Besa. Zabytek znajdujący się - podobnie jak poprzednio opisany - w kolekcji British Museum ${ }^{53}$ jest wyjątkowo interesujący, m.in. dlatego, że niewiele posiadamy zbliżonych ikonograficznie podobnych do niego przykładów, wyobrażających kapłana z maską tego bóstwa. Jak należy sądzić, figurka ta ilustruje czynność kultową ${ }^{54}$, odnoszącą się do tego wyjątkowo popularnego w okresie hellenistycznym, czy też w czasach rzymskiego panowania w Egipcie opiekuńczego obrazu boga Besa.

Rzemiosło koroplastyczne dostarcza licznych przykładów tematów, w których to narracji odnaleźć możemy cechy objaśniające, czy też ilustrujące kult lub identyfikujące same czynności rytualne. Interesujące nas szczególnie wartości edukacyjne wiązać należy z wizualnym objaśnianiem praktyk religijnych identyfikowanych z naturą teologiczną zobrazowanego bóstwa. To oczywiście jedna z wielu płaszczyzn religijnego, czy też magicznego znaczenia zabytków terakotowych. Niemniej, z racji ogromnego zbioru zabytków, jak też i licznych graficznych wariantów kompozycyjnych ujęć bóstw oraz bogiń identyfikowanych z religią grecką, czy też religią egipską, często wyobrażonych w nowej hellenistycznej formie, omawiane przedmioty zawierają szereg istotnych cech ikonograficznych, istotnych z punktu widzenia badań nad różnymi aspektami Egiptu okresu hellenistycznego i rzymskiego. Formy te, mające wiele odwołań m.in. do hellenistycznej estetyki, wiązać należy z ówczesnym odbiorcą statuarycznych wyrobów terakotowych. Tak uformowane obrazy, stanowiące często zbiór szeregu odmiennych tradycji i zawartych wątków, miały zapewne ułatwiać odpowiednie zinterpretowanie symbolicznych znaczeń, pomagając w zidentyfikowaniu licznych funkcji łączonych z wyobrażeniem plastycznym bóstw, czy też terakotowych grup, w których to wizerunek bóstwa współwystępuje. Znaczenie edukacyjne takich sformułowań identyfikowane być może z interpre-

51 Szerzej zobacz również: S. Jędraszek, Wizerunki egipskich kapłanów na przykładzie wybranych terakotowych statuetek z okresu grecko-rzymskiego - symbolika i znaczenie, „Przegląd Religioznawczy” 4 (254) 2014, s. 63-78.

52 D.M. Bailey, Catalogue of the Terracottas ... s. 60, $3153_{\mathrm{EA}}$, tabl. 27. Instrument muzyczny - jeśli zgodzimy się z interpretacją zaproponowaną przez badacza - mógł być używany w trakcie uroczystości ku czci boga Dionizosa, boga szczególnie lansowanego przez Ptolemeuszy.

53 Ibidem, s. 60, nr 3154 ${ }_{\mathrm{GR}}$, tabl. 27.

${ }^{54}$ Należy sądzić, że podczas ceremonii, czy też rytuałów identyfikowanych z tym bóstwem używano masek, które zakładano na twarz. 
tacją odnoszącą się do odpowiednich bóstw, które niekiedy wyposażone w atrybuty o różnych symbolicznych odniesieniach i związkach, umożliwiały utożsamienia obrazów czy to z religią oficjalną, czy jej prywatną płaszczyzną wiązaną z indywidualną pobożnością.

Podsumowując, należy stwierdzić, że rola edukacyjna terakotowych statuetek wydaje się być cechą stosunkowo dobrze umotywowaną w aspekcie plastycznych wizualizacji i symbolicznych odniesień, dając szereg możliwości właśnie takiej interpretacji. Cechy, jak i wartości identyfikowane z interesującą nas problematyką stanowią integralną część ówczesnej kultury, obrazując szeroko wiele aspektów życia ówczesnego społeczeństwa.

Sztuka i rzemiosło terakotowe stanowi więc nośnik wielu, często złożonych ideowo treści, o naturze i charakterze społecznym, politycznym, kulturowym, religijnym, odwołując się na płaszczyźnie obrazowania do różnorodnego, wielowarstwowego społeczeństwa Egiptu okresu grecko-rzymskiego. Jak należy sądzić, wszystkie te elementy, bez wątpienia identyfikować należy z edukacyjną funkcją licznych zabytków terakotowych, w tym także licznych grup o określonej kulturowo i historycznie tematyce, odwołującej się zarówno do kierunków, jak i postaw szczególnie lansowanych przez ówczesną władzę, mocno osadzoną kulturowo jeszcze w cywilizacji świata grecko-macedońskiego, niemniej mającą świadomość odmienności kulturowej podległego jej Egiptu. Dlatego też należy stwierdzić, że studia odwołujące się właśnie do tej kategorii zabytków, umożliwiają szersze poznanie wielu interesujących zagadnień identyfikowanych nie tylko z edukacją czy też preferowanymi modelami wychowania w duchu greckiej kultury i tradycji, lecz także z nie mniejszym wpływem egipskiego dziedzictwa i egipskiej kultury.

\section{Bibliografia}

Adriani A., Annuaire du Musée Gréco-Romain (1935-1939), Alexandrie 1940.

Adriani A., Annuaire du Musee greco-romain (1940-1950), Alexandrie 1952.

Ashour S., An Unpublished Grenite statue of Diskophoros Ephébos in Cair, BIFAO 112, 2012, s. $19-56$.

Bagnall R.S., Cribiore R., Women's letters from ancient Egypt, 300 BC-AD 800, Ann Arbor 2006.

Bailey D.M., Antaios, an Egyptian God in Roman Egypt: extracting an iconography, w: red. M. Sanader, A. Rendić-Miočević, The Proceedings of the 8th International Colloquium on Problems of Roman Provincial Art, Zagreb 2005, s. 389-398.

Bailey D.M., Catalogue of the Terracottas in the British Museum, vol. VI, Ptolemaic and Roman Terracottas from Egypt, London 2008.

Bailey D.M., Little emperors, w: red., D.M. Bailey, Archaeological Research in Roman Egypt, The Proceedings of The Seventeenth Classical Colloquium of The Department of Greek and Roman Antiquities, British Museum, held on 1-4 December, 1993, JRA Suppl. 19, Oxford 1996, s. 207-213.

Ballet P., Terres cuites gréco-égyptiennes du Musée d'Alexandrie, w: Alessandria e il mondo ellenistico-romano. I Centenario del Museo Greco-Romano (Alessandria, 23-27 Novembre 1992), Atti del II Congresso Internazionale Italo-Egiziano, «L'Erma» di Bretschneider, Roma 1995, s. 259-264, pl. XXVII-XXIX. 
Bernhard M.L., Historia starożytnej sztuki greckiej, t. IV: Sztuka hellenistyczna, IV w. p.n.e., Warszawa 1993.

Besques S., Catalogue raisonné des figurines et reliefs en terre-cuite grecs, étrusques et romaines: Époques hellénistique et romaine. Cyrénaique, Égypte ptolémaique et romaine, Afrique du Nord et Proche-Orient, Musée du Louvre 1954, Paris 1992.

Bingen J., Bagnall R.S., Hellenistic Egypt: monarchy, society, economy, culture, Berkeley 2007.

Boutantin C., Terres cuites et culte domestique: bestiaire de l'Égypte gréco-romaine, (Religions in the Graeco-Roman world 179), Leiden, Boston 2014.

Braun T.F.R.G., The Greeks in Egypt, w: The Cambridge Ancient History ${ }^{2}$ III 3, s. 32-53.

Breccia E., Municipalité d'Alexandrie. Alexandrea ad Aegyptum; Guide de la ville ancienne et moderne et du Musée gréco-romain, Bergamo 1914.

Bugh G.R., The Theseia in Late Hellenistic Athens, „Zeitschrift für Papyrologie und Epigraphik” 83, 1990, s. 20-37.

Burn L., Higgins R., Catalogue Greek terracottas in The British Museum III, London 2001.

Burr Thompson D., The Origin of Tanagras, AJA 70, 1, 1966, s. 51-63.

Burstein S.M., Kleopatra i jej rzady, przeł. B. Godzińska, Warszawa 2008.

Chauveau M., Egypt in the Age of Cleopatra. History and Society under the Ptolemies, London 2000.

Chesterman J., Collecting Classical Terracotta Figures, „Minerva” 1, 9, 1990, s. 34-36.

Cribiore R., Gymnastic of the Mind. Greek Education in Hellenistic and Roman Egypt, Princeton 2001.

Dasen V., Dwarfs in Ancient Egypt and Greece, Oxford 1993.

Dunand F., Catalogue des terres cuites grèco-romaines d'Egypte, Paris 1990.

Dunand F., Religion populaire en Egypte romaine: Les terres cuites isiaques du Musée du Caire (Études preěliminaires aux religions orientales dans l'empire romain 76), Leiden 1979.

Dunand F., Religion Populaire et iconographie en Égypte hellénistique et romaine, w: red. Kippenberg H.G. i in., Visible Religion, Annual for Religious Iconography, Popular Religion, Vol. III, Leiden 1984.

Errington R.M., Historia świata hellenistycznego 323-30 p.n.e., przeł. A. Gąsior-Niemiec, Kraków 2010.

Fischer-Bovet Ch., Army and Society in Ptolemaic Egypt, Cambridge 2014.

Fischer J., A triumphant Macedonian horseman: Evidence of a Ptolemaic Victory Monument, w: red.: N. Bonacasa, A.M. Donadoni, Roveri, S. Aiosa, P. Miná, Faraoni come dei, Tolemei come Faraoni, Atti del V Congresso Internazionale Italo-Egiziano Torino, Archivio di Stato 8-12 Dicembre 2001, Torino 2003, s. 375-380.

Fischer J., Griechisch - römische Terrakotten aus Ägypten. Die Sammlungen Sieglin und Schreiber Dresden, Leipzig, Stuttgart, Tübingen (Tübinger Studien zur Archäologie und Kunstgeschichte, Bd. 14), Tübingen 1994.

Fjeldhagen M., Catalogue of Graeco-Roman terracottas from Egypt: Ny Carlsberg Glyptotek, Copenhagen 1995.

Grant M., Cleopatra, London 1974.

Hausmann U., Zur Eroten und-Gallier, Ikonographie in alexandrinischen Kunst, w: Alessandria e il mondo ellenistico - romano, Studi in onore di Achille Adriani 5, Roma 1992, s. 283-295.

Jędraszek S., A Ptolemaic Monument to Victory over the Galatians, w: red. L. Czerniak, Gdańskie Studia Archeologiczne 2, Gdańsk 2012, s. 235-246.

Jędraszek S., Kult domowy na przykładzie wybranych zabytków kaplic terakotowych pochodzacych z Egiptu okresu grecko-rzymskiego, „Przegląd Religioznawczy” 4, 254, 2014, s. 51-61.

Jędraszek S., Religijne znaczenie sztuki koroplastów na przykładzie zabytków pochodzacych z Egiptu okresu grecko-rzymskiego, „Przegląd Religioznawczy” 3, 248, 2013, s. 3-21. 
Jędraszek S., Wizerunki egipskich kapłanów na przykładzie wybranych terakotowych statuetek z okresu grecko-rzymskiego - symbolika i znaczenie, „Przegląd Religioznawczy” 4, 254, 2014, s. $63-78$.

Jędraszek S., Wojownicze Bóstwo Bes, „Scripta Biblica Et Orientalia” 4, 2012, s. 145-177.

Jędraszek S., Wybrane aspekty odnoszące się do obecności celtyckich najemników w siłach militarnych Lagidów, w: red. D. Waszak, Celtica. Studia z dziejów Celtów, t. 1, Kalisz-Oświęcim 2013, s. 71-92.

Jędraszek S., Wybrane przyklady terakotowych przedstawień figuralnych o tematyce militarnej: Egipt okresu grecko-rzymskiego (Scripta Militaris), w: red. K. Kościelniak, Z. Pilarczyk, Wybrane problemy badawcze historii wojskowej. W pancerzu i mundurze, Torun 2014, s. 11-42.

Jędraszek S., Wybrane przykłady terakotowych statuetek wyobrażających wojowników nubijskich z Egiptu okresu grecko-rzymskiego. Temat do dyskusji, w: D. Waszak, Res Militaris II, red., [artykuł w druku].

Kingsley B.M., The cap that survived Alexander, AJA 85, 1, 1981, s. 39-46.

Kingsley B.M., The Kausia Diademophoros, AJA 88, 1, 1984, s. 66-68.

Kiss Z., Représentations des barbares dans l'iconographie romaine impériale en Égypte, „Klio” 71, 1989, s. 127-137.

Kiss Z., Un Pharaon Romain, w: red. J. Aksamit, J. Lipińska, Warsaw Egyptological Studies 1, Essays in honour of Prof. Dr. Jadwiga Lipińska, Warsaw 1997, s. 291-296.

Kleiner G., Tanagrafiguren. Untersuchungen zur hellenistischen Kunst und Geschichte, (Jahrbuch des Deutschen Archäologischen Instituts : Ergänzungsheft 15), Berlin 1942.

Laubscher H.P., Ein ptolemäisches Gallierdenkmal, „Antike Kunst” 30, 2, 1987, s. 131-154.

Launey M., Recherches sur les armées hellénistiques, I-II, Paris 1949-1950.

Leyenaar-Plaisier P.G., Les terres cuites grecques et romaines : catalogue de la collection du Musée national des antiquités a Leiden (Collections of the National Museum of Antiquities at Leiden : C.N.M.A.L., v.3), Leiden 1979.

Lipiński E., Studia z dziejów i kultury starożytnego Bliskiego Wschodu, Kraków 2013.

Łukaszewicz A., Kleopatra. Ostatnia królowa starożytnego Egiptu, Warszawa 2005.

Meeks D., Harpokrates, w: Lexikon der Ägyptologie II, Wiesbaden 1977, s. 1003-1011 (kolumny).

Meltzer E.S., Horus, [w:] D.B. Redford, The Oxford Encyclopedia of Ancient Egypt, Vol. 2, Oxford 2001, s. 119-122.

Müller S., Das hellenistische Königspaar in der medialen Repräsentation: Ptolemaios II und Arsinoe II. (Beiträge zur Altertumskunde Bd. 263, Berlin, New York 2009.

Myśliwiec K., Said M.B., Polish - Egyptian Excavations at Tell Atrib in 1994-1995, „Etudes et Travaux" 18, 1999, s. 181-219.

Naerebout F., Cuius regio, eius religio? Rulers and Religious Changes in Greco-Roman Egypt, w: red. L. Bricault, M.J. Versluys, Power, politics, and the cults of Isis .Proceedings of the Vth International Conference of Isis studies, Boulogne-sur-Mer, October 13-15, 2011, (Religions in the Graeco-Roman world Vol. 180, Boston 2014, s. 36-61.

Niwiński A., Bóstwa, kulty i rytuaty starożytnego Egiptu, Warszawa 2004.

Pawlaczyk A., De Iside et Osiride = O Izydzie i Ozyrysie, Fontes Historiae Antiquae (1998) 4, Poznań 2003.

Perdrizet P., Les terres cuites grecques d'Égypte de la collection Fouquet, Nancy-Paris-Strasbourg 1921.

Philipp H., Terrakotten aus Ägypten im Ägyptischen Museum Berli, (Bilderheft der Staatlichen Museen zu Berlin-Preussischer Kulturbesitz, Heft 18/19), Berlin 1972.

Reinach A.J., Les Galates Dans L'Art Alexandrin, „Monuments et Mémoires” 18, 1911, s. 37-116. Romanosky E., Min, w: red. D.B. Redford,The Oxford Encyclopedia of Ancient Egypt, Vol. 1, Oxford 2001, s. 413-415. 
Saatsoglou-Paliadeli Chr., Aspects of Ancient Macedonian Costume, JHS 113, 1993, s. 122-147.

Schneider-Herrmann G., About The Significance of Alexandrian Terracottas, w: Alessandria e il mondo ellenistico-Romano: studi in onore Achille Adriani, a cura di Nicola Bonacasa e Antonino di Vita. Studi e materiali 5, Roma 1984, s. 303-308, tab. LV.

Seif El-Din M., Nenna M.-D., La petite plastique en faïence du musée gréco-romain d'Alexandrie, „Bulletin de correspondance hellénique” 118, 2, 1994, s. 291-320.

Sekunda N.V., A Macedonian Companion in a Pompeian Fresco, „Archeologia” LIV, 2003, s. 29-33, tabl. X-XI.

Sekunda N.V., The Antigonid Army, (Akanthina 8), Gdańsk 2013.

Sekunda N.V., The Introduction of Cavalry Thureophoroi Into Greek Warfare, „Fasciculi Archaeologiae Historicae" 19, 2006, s. 9-17.

Szymańska H., Egipskie figurki terakotowe z okresu ptolemejskiego i cesarstwa rzymskiego w zbiorach Muzeum w Krakowie, „Materiały Archeologiczne” 21, 1981, s. 141-170.

Świderkówna A., Hellenika, Wizerunek Epoki od Aleksandra do Augusta, Warszawa 1995.

Thompson D.B., Troy, The Terracotta Figurines of the Hellenistic Period (Supplementary Monographs, 3), Princeton 1963.

Thompson H.A., Thompson D.B., Rotroff S. I., Hellenistic pottery and terracottas, Princeton 1987.

Török L., Hellenistic and Roman Terracottas from Egypt (Bibliotheca Archaeologica, 15), Roma 1995.

Vidman L., Isis und Serapis bei den Griechen und Roemern, Berlin 1970.

Vogt J., Terrakotten (Die griechisch-ägyptische Sammlung Ernst von Sieglin, Bd. 2; Expedition Ernst von Sieglin: Ausgrabungen in Alexandria, Bd. 2; Expedition Ernst Sieglin, Tl. 2.), Leipzig 1924.

Wipszycka E., O starożytności polemicznie, Warszawa 1994.

Wypustek A., Życie rodzinne starożytnych Greków, (Strefa Arche), Wrocław 2007. 